\title{
A Short-Term Study on Heavy Metal Concentrations in Gill, Kidney, Liver, Muscle and Skin Tissues of Silurus glanis L., 1758 from Çamlıgöze Dam Lake, Sivas, Turkey
}

\author{
Seher Dirican \\ Department of Fisheries, Suşehri Timur Karabal Vocational Training School, Cumhuriyet University, Sivas, Turkey
}

Email address:

sdirican@cumhuriyet.edu.tr

To cite this article:

Seher Dirican. A Short-Term Study on Heavy Metal Concentrations in Gill, Kidney, Liver, Muscle and Skin Tissues of Silurus glanis L., 1758 from Çamligöze Dam Lake, Sivas, Turkey. Journal of Health and Environmental Research. Vol. 3, No. 2, 2017, pp. 37-41.

doi: 10.11648/j.jher.20170302.14

Received: March 10, 2017; Accepted: April 14, 2017; Published: April 26, 2017

\begin{abstract}
The concentrations of heavy metals $(\mathrm{Ag}, \mathrm{Cd}, \mathrm{Cu}, \mathrm{Fe}, \mathrm{Pb})$ were analyzed in gill, kidney, liver, muscle and skin tissues of Silurus glanis L., 1758 from Çamlıgöze Dam Lake located at Central Anatolian region of Turkey. The heavy metal analysis of samples was carried out by using a flame atomic absorption spectrophotometer. $\mathrm{Ag}, \mathrm{Cd}$ and $\mathrm{Cu}$ were found in all of the examined tissues. $\mathrm{Fe}$ and $\mathrm{Pb}$ were not determined in all tissues studied. The mean concentrations of heavy metals in all of the examined tissues of S. glanis were as follows; Ag: $0.038 \pm 0.014-0.157 \pm 0.163, \mathrm{Cd}$ : $0.016 \pm 0.001-0.020 \pm 0.001$ and $\mathrm{Cu}$ : $0.045 \pm 0.001-0.346 \pm 0.434 \mu \mathrm{g} / \mathrm{g}$. The obtained results were compared in terms of national limit values, international consumed and standard values. The concentrations of the tested heavy metals were within the acceptable standards.
\end{abstract}

Keywords: Bioaccumulation, Heavy Metals, Silurus glanis, Çamlıgöze Dam Lake

\section{Introduction}

Contamination of aquatic ecosystem is unquestionably a global environmental problem. With the increasing anthropogenic activities, toxic residues are continuously mobilized from different channels to the water environment. Heavy metal pollution is a great concern because of their long persistence, bioaccumulation and biomagnifications in the food chain [1,2]. The European catfish, S. glanis, is native to eastern Europe and western Asia and is among the largest freshwater fish in the world. Despite its increasing economic importance and its frequent introductions, the ecology and life history of this species is poorly known due to the difficulty of sampling such a large species in large rivers and standing waters. The European catfish has an economic importance in commercial and recreational fisheries as well as in aquaculture. S. glanis is an economically valuable fish due to its very tasty flesh and lives in all freshwaters of Turkey except for Southeast Anatolia and the southern part of Eastern Anatolia $[3,4]$. Predator fish like European catfish are at the top of food chain in the ecosystem, and can reflect the ambient metal concentrations [5]. The aim of this study was carried out to investigate bioaccumulation of heavy metals $(\mathrm{Ag}, \mathrm{Cd}$, $\mathrm{Cu}, \mathrm{Fe}, \mathrm{Pb}$ ) in gill, kidney, liver, muscle and skin tissues of $S$. glanis from Çamlıgöze Dam Lake located at Central Anatolian region of Turkey.

\section{Materials and Methods}

\subsection{Description of Study Area}

This study was conducted in a manmade dam lake of Çamlıgöze in Sivas, Turkey. Çamlıgöze Dam Lake is located at Central Anatolian region of Turkey (Figure 1), longitude $40^{\circ}$ 13' 45" N and latitude 38 04' 36" E. The Çamlıgöze Dam was constructed between 1987 and 1998 on the Kelkit Stream, a tributary of Yeşilırmak River. Çamlıgöze Dam is a $37 \mathrm{~m}$ high rockfill a power plant. The water of Çamlıgöze Dam Lake is mainly used for produce electrical energy, aquaculture, commercial fishing, irrigation, and recreation. The surface area and maximum depth of the Çamlıgöze Dam Lake are 5 $\mathrm{km}^{2}$ and $30 \mathrm{~m}$ respectively. Average capacity of Çamlıgöze 
Dam Hydroelectric Station is $102 \mathrm{GWh} /$ year [6].

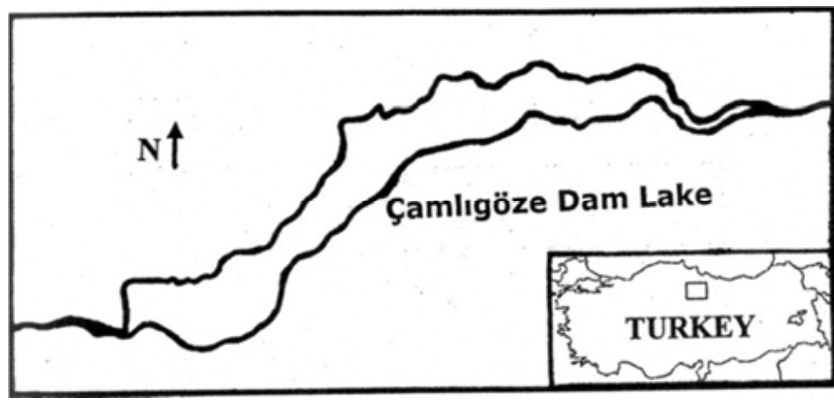

Figure 1. Çamlıg̈̈e Dam Lake.

\subsection{Sampling and Sample Preparation}

S. glanis specimens used in this study were caught with nets of $90 \mathrm{~mm}$ mesh sizes from Çamlıgöze Dam Lake in January 2011. Fish samples were transferred to the laboratory to record total body length and total wet weight. Body weight and total length of each individual were measured with a precision of $0.1 \mathrm{~g}$ and $0.1 \mathrm{~cm}$, respectively. Fish samples were washed with water, packed in polyethylene bags and stored at $-20{ }^{0} \mathrm{C}$ until analysis. Approximatelly 1 or $2 \mathrm{~g}$ of the gill, kidney, liver, muscle and skin samples were dissected from two fish specimens. The soft tissues were extracted from each fish samples using a plastic knife. After they were individually transferred to 20 $\mathrm{ml}$ glass vials previously washed with $0.1 \mathrm{~N}$ nitric acid, dried and weighed, they were dried for 24 hours at $105^{\circ} \mathrm{C}$ and kept in an oven. Then samples were kept at room temperature for 24 hours by adding $3 \mathrm{ml}$ nitric acid. Then samples can withstand heat very low heats on a hot metal plate until the color disappears slowly heated vapors have been mineralized. Then the samples were added to $1 \mathrm{ml}$ sulfuric acid. The samples were added into the 1-2 drops of nitric acid. The digested samples were diluted to $50 \mathrm{ml}$ with distilled water [6-8]. The solution was transferred and filtered through 0.45 $\mu \mathrm{m}$ nitrocellulose membrane filter and ready for analysis [9]. Analysis of the heavy metals in the samples was carried out using a flame atomic absorption spectrophotometer to determine the concentrations of $\mathrm{Ag}, \mathrm{Cd}, \mathrm{Cu}, \mathrm{Fe}$ and $\mathrm{Pb}$. The concentrations of $\mathrm{Ag}, \mathrm{Cd}, \mathrm{Cu}, \mathrm{Fe}$ and $\mathrm{Pb}$ metals were expressed as $\mu \mathrm{g} / \mathrm{g}$ (wet weight). $\mathrm{Ag}$ was measured at wavelength $328.100 \mathrm{~nm}, \mathrm{Cd}$ at $228.802 \mathrm{~nm}, \mathrm{Cu}$ at 327.393 $\mathrm{nm}, \mathrm{Fe}$ at $328.204 \mathrm{~nm}$ and $\mathrm{Pb}$ at $220.353 \mathrm{~nm}$. The values below detection limits were assigned as "ND" in the study.

\section{Results}

A total of two specimens of $S$. glanis were caught from Çamlıgöze Dam Lake. Some morphometric characteristics of $S$. glanis from Çamlıöze Dam Lake are given in Table 1. The total length of $S$. glanis population from Çamligöze Dam Lake ranged from 78.7 to $94.4 \mathrm{~cm}$. The mean total length of all $S$. glanis samples was determined $86.55 \pm 11.10$. Weights of $S$. glanis ranged from 1866.2 to $2213.9 \mathrm{~g}$. The mean weight of all S. glanis samples was determined 2040.05 \pm 245.86 from
Çamlıgöze Dam Lake.

Table 1. Some morphometric characteristics of S. glanis.

\begin{tabular}{lccc}
\hline Species & N & $\begin{array}{c}\text { Total Length }(\mathbf{c m}) \\
\text { Mean } \pm \text { SD }\end{array}$ & $\begin{array}{c}\text { Weight }(g) \\
\text { Mean } \pm \text { SD }\end{array}$ \\
\hline Silurus glanis & 2 & $\begin{array}{c}86.55 \pm 11.10 \\
(78.7-94.4)\end{array}$ & $\begin{array}{l}2040.05 \pm 245.86 \\
(1866.2-2213.9)\end{array}$ \\
\hline
\end{tabular}

$\mathrm{N}$ : number of observations, SD: standard deviation, minimum and maximum values are given in parentheses.

The mean concentrations of heavy metals in gill, kidney, liver, muscle and skin of $S$. glanis are summarized in Table 2. $\mathrm{Ag}, \mathrm{Cd}$ and $\mathrm{Cu}$ were detected in all of the examined tissues. $\mathrm{Fe}$ and $\mathrm{Pb}$ were not detected in all of the examined tissues. The mean heavy metal concentrations were determined in gill as follows; Ag: $0.038 \pm 0.014 \mu \mathrm{g} / \mathrm{g}, \mathrm{Cd}: 0.017 \pm 0.001 \mu \mathrm{g} / \mathrm{g}, \mathrm{Cu}$ : $0.045 \pm 0.001 \mu \mathrm{g} / \mathrm{g}$. The mean heavy metal concentrations were determined in kidney as follows; Ag: $0.157 \pm 0.163 \mu \mathrm{g} / \mathrm{g}, \mathrm{Cd}$ : $0.020 \pm 0.001 \mu \mathrm{g} / \mathrm{g}, \mathrm{Cu}: 0.121 \pm 0.021 \mu \mathrm{g} / \mathrm{g}$. The mean heavy metal concentrations were determined in liver as follows; Ag: $0.048 \pm 0.015 \mu \mathrm{g} / \mathrm{g}, \quad \mathrm{Cd}: \quad 0.018 \pm 0.005 \mu \mathrm{g} / \mathrm{g}, \quad \mathrm{Cu}$ : $0.121 \pm 0.005 \mu \mathrm{g} / \mathrm{g}$. The mean heavy metal concentrations were determined in muscle as follows; Ag: $0.048 \pm 0.015 \mu \mathrm{g} / \mathrm{g}, \mathrm{Cd}$ : $0.016 \pm 0.001 \mu \mathrm{g} / \mathrm{g}, \mathrm{Cu}: 0.093 \pm 0.076 \mu \mathrm{g} / \mathrm{g}$. The mean heavy metal concentrations were determined in skin as follows; Ag: $0.052 \pm 0.030 \mu \mathrm{g} / \mathrm{g}, \mathrm{Cd}: 0.017 \pm 0.001 \mu \mathrm{g} / \mathrm{g}, \mathrm{Cu}: 0.346 \pm 0.434$ $\mu \mathrm{g} / \mathrm{g}$ from Çamlıgöze Dam Lake (Table 2). The patterns of the mean metal occurrence in the selected tissues can be listed as follows in descending order; Silver $(\mathrm{Ag})$ : Kidney $>$ Skin $>$ Muscle $>$ Liver $>$ Gill, Cadmium $(\mathrm{Cd})$ : Kidney $>$ Liver $>$ Gill $=$ Skin $>$ Muscle and Copper $(\mathrm{Cu})$ : Skin $>$ Kidney $=$ Liver $>$ Muscle $>$ Gill in S. glanis. The mean concentrations in the tissues of $S$. glanis were found as follows: $\mathrm{Cu}>\mathrm{Ag}>\mathrm{Cd}$ in gill, liver, muscle and skin; $\mathrm{Ag}>\mathrm{Cu}>\mathrm{Cd}$ in kidney.

Generally, the results verify the differences of heavy metal accumulation in different tissues. Concentrations of metals varied depending on different tissues in S. glanis from Çamlıgöze Dam Lake. The study data showed that, skin accumulated the highest concentration while liver accumulated the lowest. The gill of $S$. glanis had the highest levels of $\mathrm{Ag}(0.048 \mu \mathrm{g} / \mathrm{g}), \mathrm{Cd}(0.018 \mu \mathrm{g} / \mathrm{g})$ and $\mathrm{Cu}(0.045$ $\mu \mathrm{g} / \mathrm{g})$. Similarly, the kidney had the highest levels of $\mathrm{Ag}$ $(0.272 \mu \mathrm{g} / \mathrm{g}), \mathrm{Cd}(0.021 \mu \mathrm{g} / \mathrm{g})$ and $\mathrm{Cu}(0.135 \mu \mathrm{g} / \mathrm{g})$. The liver had the highest concentrations of $\mathrm{Ag}(0.048 \mu \mathrm{g} / \mathrm{g}), \mathrm{Cd}(0.021$ $\mu \mathrm{g} / \mathrm{g})$ and $\mathrm{Cu}(0.124 \mu \mathrm{g} / \mathrm{g})$. The muscle had the highest concentrations of $\mathrm{Ag}(0.058 \mu \mathrm{g} / \mathrm{g}), \mathrm{Cd}(0.016 \mu \mathrm{g} / \mathrm{g})$ and $\mathrm{Cu}$ $(0.146 \mu \mathrm{g} / \mathrm{g})$. The skin had the highest concentrations of $\mathrm{Ag}$ $(0.073 \mu \mathrm{g} / \mathrm{g}), \mathrm{Cd}(0.018 \mu \mathrm{g} / \mathrm{g})$ and $\mathrm{Cu}(0.652 \mu \mathrm{g} / \mathrm{g})$ in $S$. glanis The highest $\mathrm{Ag}(0.272 \mu \mathrm{g} / \mathrm{g})$ and $\mathrm{Cd}(0.021 \mu \mathrm{g} / \mathrm{g})$ concentration was determined in kidney of $S$. glanis. The highest accumulation of $\mathrm{Cu}$ was observed in skin with 0.652 $\mu \mathrm{g} / \mathrm{g}$ while the lowest accumulation of $\mathrm{Cd}$ was observed in liver with $0.014 \mu \mathrm{g} / \mathrm{g}$ in Çamlıgöze Dam Lake.

In the fish gill $\mathrm{Ag}, \mathrm{Cd}$ and $\mathrm{Cu}$ concentrations varied between $0.016 \mu \mathrm{g} / \mathrm{g}$ tissue and $0.048 \mu \mathrm{g} / \mathrm{g}$ tissue. The highest concentrations were measured for silver. Similarly, in the fish kidney $\mathrm{Ag}, \mathrm{Cd}$ and $\mathrm{Cu}$ concentrations varied between 0.019 
$\mu \mathrm{g} / \mathrm{g}$ tissue and $0.272 \mu \mathrm{g} / \mathrm{g}$ tissue. The highest concentrations were measured for silver. In the fish liver $\mathrm{Ag}, \mathrm{Cd}$ and $\mathrm{Cu}$ concentrations varied between $0.014 \mu \mathrm{g} / \mathrm{g}$ tissue and 0.124 $\mu \mathrm{g} / \mathrm{g}$ tissue. The highest concentrations were measured for copper. In the fish muscle $\mathrm{Ag}, \mathrm{Cd}$ and $\mathrm{Cu}$ concentrations varied between $0.015 \mu \mathrm{g} / \mathrm{g}$ tissue and $0.146 \mu \mathrm{g} / \mathrm{g}$ tissue. The highest concentrations were measured for copper. In the fish skin $\mathrm{Ag}, \mathrm{Cd}$ and $\mathrm{Cu}$ concentrations varied between $0.016 \mu \mathrm{g} / \mathrm{g}$ tissue and $0.652 \mu \mathrm{g} / \mathrm{g}$ tissue (Table 2). The highest concentrations were measured for copper.

\section{Discussion}

Concentrations of heavy metal varied depending on different tissues. The results of this study indicated that general accumulation of $\mathrm{Ag}, \mathrm{Cd}$ and $\mathrm{Cu}$ in the gill, kidney, liver, muscle and skin of $S$. glanis. The highest accumulation of $\mathrm{Ag}$ was observed in kidney with $0.272 \mu \mathrm{g} / \mathrm{g}$ while the lowest accumulation of $\mathrm{Ag}$ was observed in gill with 0.028 $\mu \mathrm{g} / \mathrm{g}$. The Ag concentrations in tissues varied from $0.028 \mu \mathrm{g} / \mathrm{g}$ to $0.048 \mu \mathrm{g} / \mathrm{g}$, mean value of $0.038 \pm 0.014 \mu \mathrm{g} / \mathrm{g}$ in gill, 0.041 to $0.272 \mu \mathrm{g} / \mathrm{g}$, mean value of $0.157 \pm 0.163 \mu \mathrm{g} / \mathrm{g}$ in kidney, 0.037 to $0.048 \mu \mathrm{g} / \mathrm{g}$, mean value of $0.043 \pm 0.008 \mu \mathrm{g} / \mathrm{g}$ in liver, 0.037 to $0.058 \mu \mathrm{g} / \mathrm{g}$, mean value of $0.048 \pm 0.015 \mu \mathrm{g} / \mathrm{g}$ in muscle and 0.030 to $0.073 \mu \mathrm{g} / \mathrm{g}$, mean value of $0.052 \pm 0.030 \mu \mathrm{g} / \mathrm{g}$ in skin for S. glanis in Çamlıgöze Dam Lake (Table 2). Ag is one of the most toxic but least studied of the heavy metals in aquatic ecosystems. Although Ag has received little environmental attention, it is a very toxic metal, it occurs in industrial discharges, and it must be considered in any classification of highly toxic pollutants. Ag in minute amounts in water, is very toxic to fish $[10,11]$. The mean $\mathrm{Ag}$ values in muscle and liver of $S$. glanis obtained in this study were lower than those obtained by Dirican et al. [11] in Barbus plebejus, Cyprinus carpio and Squalius cephalus from Kiliçkaya Dam Lake, Turkey. There is no information about acceptable limit of Ag in fish tissues.

Table 2. Heavy metals concentrations in tissues of S. glanis from Çamligöze Dam Lake.

\begin{tabular}{|c|c|c|c|c|c|}
\hline Elements & $\begin{array}{c}\text { Gill } \\
\text { Mean } \pm \text { SD } \\
\end{array}$ & $\begin{array}{c}\text { Kidney } \\
\text { Mean } \pm \text { SD }\end{array}$ & $\begin{array}{c}\text { Liver } \\
\text { Mean } \pm \text { SD }\end{array}$ & $\begin{array}{c}\text { Muscle } \\
\text { Mean } \pm \text { SD } \\
\end{array}$ & $\begin{array}{c}\text { Skin } \\
\text { Mean } \pm \text { SD }\end{array}$ \\
\hline $\mathrm{Ag}$ & $\begin{array}{c}0.038 \pm 0.014 \\
(0.028-0.048)\end{array}$ & $\begin{array}{c}0.157 \pm 0.163 \\
(0.041-0.272)\end{array}$ & $\begin{array}{c}0.043 \pm 0.008 \\
(0.037-0.048)\end{array}$ & $\begin{array}{c}0.048 \pm 0.015 \\
(0.037-0.058)\end{array}$ & $\begin{array}{c}0.052 \pm 0.030 \\
(0.030-0.073)\end{array}$ \\
\hline $\mathrm{Cd}$ & $\begin{array}{c}0.017 \pm 0.001 \\
(0.016-0.018)\end{array}$ & $\begin{array}{c}0.020 \pm 0.001 \\
(0.019-0.021)\end{array}$ & $\begin{array}{c}0.018 \pm 0.005 \\
(0.014-0.021)\end{array}$ & $\begin{array}{c}0.016 \pm 0.001 \\
(0.015-0.016)\end{array}$ & $\begin{array}{c}0.017 \pm 0.001 \\
(0.016-0.018)\end{array}$ \\
\hline $\mathrm{Cu}$ & $\begin{array}{c}0.045 \pm 0.001 \\
(0.044-0.045)\end{array}$ & $\begin{array}{c}0.121 \pm 0.021 \\
(0.106-0.135)\end{array}$ & $\begin{array}{c}0.121 \pm 0.005 \\
(0.117-0.124)\end{array}$ & $\begin{array}{c}0.093 \pm 0.076 \\
(0.039-0.146)\end{array}$ & $\begin{array}{c}0.346 \pm 0.434 \\
(0.039-0.652)\end{array}$ \\
\hline
\end{tabular}

SD: standard deviation, ND: not detected, minimum and maximum values are given in parentheses.

The highest $\mathrm{Cd}$ concentration was observed in kidney and liver of $S$. glanis $(0.021 \mu \mathrm{g} / \mathrm{g})$, while the lowest $(0.014 \mu \mathrm{g} / \mathrm{g})$ was in liver. The $\mathrm{Cd}$ concentrations in tissues varied from $0.016 \mu \mathrm{g} / \mathrm{g}$ to $0.018 \mu \mathrm{g} / \mathrm{g}$, mean value of $0.017 \pm 0.001 \mu \mathrm{g} / \mathrm{g}$ in gill, 0.019 to $0.021 \mu \mathrm{g} / \mathrm{g}$, mean value of $0.020 \pm 0.001 \mu \mathrm{g} / \mathrm{g}$ in kidney, 0.014 to $0.021 \mu \mathrm{g} / \mathrm{g}$, mean value of $0.018 \pm 0.005 \mu \mathrm{g} / \mathrm{g}$ in liver, 0.015 to $0.016 \mu \mathrm{g} / \mathrm{g}$, mean value of $0.016 \pm 0.001 \mu \mathrm{g} / \mathrm{g}$ in muscle and 0.016 to $0.018 \mu \mathrm{g} / \mathrm{g}$, mean value of $0.017 \pm 0.001$ $\mu \mathrm{g} / \mathrm{g}$ in skin for S. glanis in Çamlıgöze Dam Lake (Table 2). The mean Cd values in skin of $S$. glanis obtained in the study were lower than those obtained by Karadede et al. [12] in $S$. triostegus from Atatürk Dam Lake, Turkey. The mean $\mathrm{Cd}$ values in gill, kidney and liver of $S$. glanis obtained in the study were lower than those obtained by Jovicic et al. [13] in S. glanis from Danube River, Serbia. On the contrary, the mean $\mathrm{Cd}$ values in muscle of $S$. glanis obtained in the study were higher than those obtained by Jovicic et al. [13] in the same species from Danube River, Serbia. The mean $\mathrm{Cd}$ values in liver and muscle of $S$. glanis obtained in the study were higher than those obtained by Ivanovic et al. [14] in the same species from Danube River, Serbia. The mean $\mathrm{Cd}$ values in liver and muscle of $S$. glanis obtained in the study were higher than those obtained by Milanov et al. [15] in the same species from Danube River, Serbia. For $\mathrm{Cd}(\mu \mathrm{g} / \mathrm{g})$ Malaysian Food Regulation is 1.00, Hong Kong Environmental Protection Department 2.00 and United States
Food and Drug Administration 3.70 [16-18].

The highest accumulation of $\mathrm{Cu}$ was observed in skin with $0.652 \mu \mathrm{g} / \mathrm{g}$ while the lowest accumulation of $\mathrm{Cu}$ was observed in muscle and skin with $0.039 \mu \mathrm{g} / \mathrm{g}$ in $S$. glanis. The $\mathrm{Cu}$ concentrations in tissues varied from $0.044 \mu \mathrm{g} / \mathrm{g}$ to $0.045 \mu \mathrm{g} / \mathrm{g}$, mean value of $0.045 \pm 0.001 \mu \mathrm{g} / \mathrm{g}$ in gill, 0.106 to $0.135 \mu \mathrm{g} / \mathrm{g}$, mean value of $0.121 \pm 0.021 \mu \mathrm{g} / \mathrm{g}$ in kidney, 0.117 to 0.124 $\mu \mathrm{g} / \mathrm{g}$, mean value of $0.121 \pm 0.005 \mu \mathrm{g} / \mathrm{g}$ in liver, 0.039 to 0.146 $\mu \mathrm{g} / \mathrm{g}$, mean value of $0.093 \pm 0.076 \mu \mathrm{g} / \mathrm{g}$ in muscle and 0.039 to $0.652 \mu \mathrm{g} / \mathrm{g}$, mean value of $0.346 \pm 0.434 \mu \mathrm{g} / \mathrm{g}$ in skin for $S$. glanis in Çamlıgöze Dam Lake (Table 2). The mean $\mathrm{Cu}$ values in all of the examined tissues of $S$. glanis obtained in this study were lower than those obtained by Mendil and Uuözlü [19] in S. glanis from Ataköy Dam Lake, Turkey. The mean $\mathrm{Cu}$ values in gill, liver and muscle of $S$. glanis obtained in the study were lower than those obtained by Ali et al. [20] in S. glanis from Ladgo Lake, Cameroun. The mean $\mathrm{Cu}$ values in muscle of $S$. glanis obtained in the study were lower than those obtained by Küpeli et al. [21] in the same species from Sakarya River, Turkey. The mean $\mathrm{Cu}$ values in gill, kidney, liver and muscle of $S$. glanis obtained in the study were lower than those obtained by Jovicic et al. [13] in the same species from Danube River, Serbia. The mean $\mathrm{Cu}$ values in liver and muscle of $S$. glanis obtained in the study were higher than those obtained by Lenhardt et al. [22] in $S$. glanis from Danube River, Serbia. The permissible limits 
proposed by the FAO, WHO and Turkish legislation established the following maximum levels for the metals studied, above which consumption is not permitted: $0.1 \mu \mathrm{g} / \mathrm{g}$ for $\mathrm{Cd}, 5 \mu \mathrm{g} / \mathrm{g}$ for $\mathrm{Cu}$ and $0.5 \mu \mathrm{g} / \mathrm{g}$ or $1 \mu \mathrm{g} / \mathrm{g}$ for $\mathrm{Pb}$ [23-25]. According to international criteria and Turkish regulation, heavy metal concentrations especially $\mathrm{Cd}, \mathrm{Cu}$ and $\mathrm{Pb}$ in Çamlıgöze Dam Lake were found below the permissible levels for examined tissues of $S$. glanis. There is also legislation in other countries regulating the maximum concentration of metals. For example, Spanish legislation limits the levels for $\mathrm{Cd}$ at $1 \mu \mathrm{g} / \mathrm{g}, \mathrm{Cu}$ at $20 \mu \mathrm{g} / \mathrm{g}$ and $\mathrm{Pb}$ at 2 $\mu \mathrm{g} / \mathrm{g}[26,27]$. According to Spanish legislation limits, heavy metal concentrations $\mathrm{Pb}$ in Çamlıgöze Dam Lake were below the permissible levels for tissues of $S$. glanis. For $\mathrm{Cu}(\mu \mathrm{g} / \mathrm{g})$ Canadian Food Standard is 100, Hungarian standard 60, the range of international standard 10-100 and Turkish Food Codex acceptable limit 20 [28-30]. The comparison showed that our $\mathrm{Cu}$ values are lower than the guidelines. A comparison with the European Community food standards [31] for fish Cd: $0.05-0.10 \mu \mathrm{g} / \mathrm{g}$ and $\mathrm{Pb}: 0.2-0.4 \mu \mathrm{g} / \mathrm{g}$. According to European Community food standards, heavy metal concentrations $\mathrm{Cd}$ and $\mathrm{Pb}$ in Çamlıöze Dam Lake were found below the permissible levels for examined tissues of $S$. glanis. These limits were not exceeded in the gill, kidney, liver, muscle and skin of $S$. glanis analyzed in this study.

\section{Conclusion}

These results suggest that $S$. glanis living in Çamligöze Dam Lake are not heavily burdened with metals. Therefore, conclude that this metals presents no problem for utilization in human consumption of $S$. glanis at this time. Nevertheless, in the future, bioaccumulation of metals, especially $\mathrm{Ag}, \mathrm{Cd}$ and $\mathrm{Cu}$ may emerge a potential risk for the human consumption of this fish. The data obtained in this study bring new knowledge on the Çamligöze Dam Lake aquatic ecosystem in Turkey. The study provides beneficial information, as studied the fish species also represent major object of commercial fishery in Çamlıgöze Dam Lake in Turkey. The current results demonstrate the scientific and practical need for a continuous monitoring of the dynamics of bioaccumulation of heavy metals in $S$. glanis tissue and will serve as a base in further studies in Çamlıgöze Dam Lake.

\section{References}

[1] Damian, E. C., Afulenu, N. L., Obinna, O. M. and Ndidi, O. C. 2014. Bioaccumulation of heavy metals in fish sourced from environmentally stressed axis of River Niger: Threat to ecosystem and public health. International Journal of Environmental Protection and Policy, 2 (4): 126-131. DOI: 10.11648/j.ijepp.20140204.11.

[2] Bhuyan, M. S., Bakar, M. A., Islam, M. S. and Akhtar, A. 2016. Heavy metals status in some commercially important fishes of Meghna River adjacent to Narsingdi District, Bangladesh: Health risk assessment. American Journal of Life Sciences, 4 (2): 60-70. DOI: 10.11648/j.ajls.20160402.17.
[3] Bora, N. D. and Gül, A. 2004. Feeding biology of Silurus glanis (L., 1758) living in Hirfanlı Dam Lake. Turkish Journal of Veterinary and Animal Sciences, 28: 471-479.

[4] Alp, A., Kara, C., Üçkardeş, F., Carol, J. and Garcia-Berthou, E. 2011. Age and growth of the European catfish (Silurus glanis) in a Turkish Reservoir and comparison with introduced populations. Reviews in Fish Biology and Fisheries, 21: 283294. DOI: $10.1007 / \mathrm{s} 11160-010-9168-4$.

[5] Squadrone, S., Prearo, M., Brizio, P., Gavinelli, S., Pellegrino, M., Scanzio, T., Guarise, S., Benedetto, A. and Abete, M. C. 2013. Heavy metals distribution in muscle, liver, kidney and gill of European catfish (Silurus glanis) from Italian Rivers. Chemosphere, 90: 358-365.

[6] Dirican, S., Çilek, S., Çiftçi, H., Bıyıkoğlu, M., Karaçınar, S. and Yokuş, A. 2013. Preliminary study on heavy metal concentrations of Anatolian Khramulya, Capoeta tinca (Heckel, 1843) from Çamlıgöze Dam Lake, Sivas, Turkey. Journal of Environmental Health Science and Engineering, 11 (7): DOI: $10.1186 / 2052-336 X-11-7$.

[7] Çalta, M., Canpolat, O. and Nacar, A. 2000. Determining the level of some heavy metals of Capoeta trutta (Heckel, 1843) caught in Elazığ Keban Dam Lake. (in Turkish), Eastern Anatolia Region IV. Symposium of Fisheries, Erzurum, Turkey, 799-811.

[8] Çalta, M. and Canpolat, O. 2006. The comparison of three Cyprinid species in terms of heavy metals accumulation in some tissues. Water Environment Research, 78 (5): 548-551.

[9] Alam, M. G. M., Tanaka, A., Allinson, G., Laurenson, L. J. B., Stagnitti, F. and Snow, E. 2002. A comparison of trace element concentrations in cultured and wild carp (Cyprinus carpio) of Lake Kasumigaura, Japan. Ecotoxicology and Environmental Safety, 53: 348-354.

[10] Campbell, K. R. 1995. Bioaccumulation of heavy metals in fish living in stormwater treatment ponds, St. Johns River Water Management District Palatka, Florida, Technical Publication SJ95-1, 100 pp.

[11] Dirican, S., Çilek, S., Çiftçi, H., Bıyıkoğlu, M., Karaçınar, S. and Yokuş, A. 2015. Studies on copper, silver and zinc concentrations in muscle and liver of Barbus plebejus, Cyprinus carpio and Leuciscus cephalus from K1liçkaya Reservoir in Turkey. Indian Journal of Animal Research, 49 (1): 55-58. DOI: 10.5958/0976-0555.2015.00012.6.

[12] Karadede, H., Oymak, S. A. and Ünlü, E. 2004. Heavy metals in mullet, Liza abu, and catfish, Silurus triostegus, from the Atatürk Dam Lake (Euphrates), Turkey. Environment International, 30: 183-188. DOI: 10.1016/S0160-4120(03) 00169-7.

[13] Jovicic, K., Dragica, M. N., Visnjic-Jeftic, Z., Dikanovic, V., Skoric, S., Stefanovic, S. M., Lenhardt, M., Hegedis, A., Krpo-Cetkovic, J. and Jaric, I. 2015. Mapping differential elemental accumulation in fish tissues: assessment of metal and trace element concentrations in wels catfish (Silurus glanis) from the Danube River by ICP-MS. Environmental Science and Pollution Research, 22: 3820-3827. DOI: 10.1007/s11356 -014-3636-7.

[14] Ivanovic, J., Janjic, J., Baltic, M., Milanov, R., Boskovic, M., Radmila V. Markovic, R. V. and Glamoclija, N. 2016. Metal concentrations in water, sediment and three fish species from the Danube River, Serbia: a cause for environmental concern. Environmental Science and Pollution Research, 23: 1710517112. DOI: $10.1007 / \mathrm{s} 11356-016-6875-\mathrm{y}$. 
[15] Milanov, R., Krstic, P. M., Markovic, V. R., Jovanovic, A. D., Baltic, M. B. Ivanovic, J., Jovetic, M. and Baltic, Z. M. 2016. Analysis of heavy metals concentration in tissues of three different fish species included in human diet from Danube River. Acta Veterinaria, 66: (1): 89-102. DOI: 10.1515/acve -2016-0007.

[16] MFR, 1985. Malaysian Food Regulation, Malaysian law on food and drugs. Malaysian Law Publishers, Malaysia.

[17] HKEPD, 1987. Marine water quality in Hong Kong, Hong Kong Environmental Protection Department, Government Printer, Hong Kong.

[18] USFDA., 1993. Guidance documents for trace elements in seafood. United States Food and Drug Administration, Washington DC, USA.

[19] Mendil, D. and Uluözlü, O. D. 2007. Determination of trace metal levels in sediment and five fish species from lakes in Tokat, Turkey. Food Chemistry, 101: 739-745.

[20] Ali, A., Ahmadou, D., Mohamadou, B. A., Saidou, C. and Tenin, D. 2010. Determination of minerals and heavy metals in water, sediments and three fish species (Tilapia nilotica, Silurus glanis and Arius parkii) from Ladgo Lake, Cameroun. Journal of Fisheries International, 5(3): 54-57.

[21] Küpeli, T., Altundağ, H. and İmamoğlu, M. 2014. Assessment of trace element levels in muscle tissues of fish species collected from a river, stream, lake, and sea in Sakarya, Turkey. Scientific World Journal, 1-7. DOI: 10.1155/2014/496107.

[22] Lenhardt, M., Jaric, I., Visnjic-Jeftic, Z., Skoric, C., Gacic, Z. Pucar, M. and Hegedis, A. 2012. Concentrations of 17 elements in muscle, gills, liver and gonads of five economically important fish species from the Danube River. Knowledge and Management of Aquatic Ecosystems, 407: 1-9. DOI: 10.1051/ $\mathrm{kmae} / 2012028$.
[23] FAO/WHO, 1989. Evaluation of certain food additives and contaminants mercury, lead and cadmium. WHO Technical Report Series No: 505.

[24] WHO, 1993. World Health Organization, Forty-first Report of the Join Expert Committee on Food Additives (JEFCA). Technical Report Series, No: 837, 53 pp.

[25] ITS, 2000. Institute of Turkish Standards for Food. The Ministry of the Agriculture of Turkey, Report 5.

[26] Usero, J., Izquierdo, C., Morillo, J. and Gracia, I. 2003. Heavy metals in fish (Solea vulgaris, Anguilla anguilla and Liza aurata) from salt marshes on the southern Atlantic Coast of Spain. Environment International, 1069: 1-8.

[27] Demirak, A., Y1lmaz, F., Tuna, A. L. and Özdemir, N. 2006. Heavy metals in water, sediment and tissues of Leuciscus cephalus from a stream in southwestern Turkey. Chemosphere, 63: 1451-1458. DOI:10.1016/j.chemosphere.2005.09.033.

[28] TFC, 2002. Turkish Food Codes, Official Gazette, 23 September 2002, No: 24885.

[29] Papagiannis, I., Kagalou, I., Leonardos, J., Petridis, D. and Kalfakakou, V. 2004. Copper and zinc in four freshwater fish Species from Lake Pamvotis (Greece). Environment International, 30: 357-362.

[30] Yılmaz, F., Özdemir, N., Demirak, A. and Tuna, A. L. 2007. Heavy metal levels in two fish species Leuciscus cephalus and Lepomis gibbosus. Food Chemistry, 100(2): 830-835. DOI: 10.1016/j.foodchem.2005.09.020.

[31] EC, 2001. European Community, Commission regulation as regards heavy metals. Directive 2001/22/EC. No: 466/2001 of 8 March 2001. 